University of Nebraska - Lincoln

DigitalCommons@University of Nebraska - Lincoln

2012

\title{
Direct carbon fuel cell: A proposed hybrid design to improve commercialization potential
}

Justin Ruflin

Contained Energy LLC, jruflin@gmail.com

Alexander D. Perwich II

Contained Energy LLC, aperwich@gmail.com

Chris Brett

Contained Energy LLC

J. Kevin Berner

Contained Energy LLC

Scott M. Lux

U.S. Army Engineer Research and Development Center

Follow this and additional works at: https://digitalcommons.unl.edu/usarmyresearch

Ruflin, Justin; Perwich, Alexander D. II; Brett, Chris; Berner, J. Kevin; and Lux, Scott M., "Direct carbon fuel cell: A proposed hybrid design to improve commercialization potential" (2012). US Army Research. 220. https://digitalcommons.unl.edu/usarmyresearch/220

This Article is brought to you for free and open access by the U.S. Department of Defense at DigitalCommons@University of Nebraska - Lincoln. It has been accepted for inclusion in US Army Research by an authorized administrator of DigitalCommons@University of Nebraska - Lincoln. 


\title{
Direct carbon fuel cell: A proposed hybrid design to improve commercialization potential
}

\author{
Justin Ruflin $^{\mathrm{a}}$, Alexander D. Perwich II ${ }^{\mathrm{a}, *}$, Chris Brett ${ }^{\mathrm{a}}$, J. Kevin Berner ${ }^{\mathrm{a}}$, Scott M. Lux ${ }^{\mathrm{b}}$ \\ ${ }^{a}$ Contained Energy LLC, 51 Alpha Park, Highland Heights, OH 44143, USA \\ ${ }^{\mathrm{b}}$ Construction Engineering Research Laboratory (CERL), U.S. Army Engineer Research and Development Center, 2902 Newmark Dr., Champaign, IL 61822, USA
}

\section{A R T I C L E I N F O}

\section{Article history:}

Received 26 March 2012

Received in revised form

9 April 2012

Accepted 10 April 2012

Available online 25 April 2012

\section{Keywords:}

Direct carbon fuel cell

Carbon

Molten carbonate fuel cell

Solid oxide fuel cell

\begin{abstract}
A B S T R A C T
This paper summarizes Contained Energy, LLC's (CEL's) 2 year work effort to produce a DCFC single cell with a minimum performance of 120 W.L-1 at $50 \%$ efficiency. It explains the challenge of high temperature that is required to get the power densities necessary to produce feasible-sized operational units and also explains problems encountered with partial oxidation of the carbon at those temperatures which causes low efficiencies. Finally, in an attempt to balance these two opposing parameters, CEL introduces a novel ceramic DCFC concept, reviews lessons learned and makes recommendations for future DCFC work.
\end{abstract}

(ㄷ) 2012 Elsevier B.V. All rights reserved.

\section{Introduction}

\subsection{Background}

The direct carbon fuel cell (DCFC), a technology that dates back to the mid-19th century [1,2], converts the chemical energy of solid carbon fuel to electricity with an efficiency far superior to coal-fired generation and greater than many other fuel cell technologies [3-5].

With a potential operating efficiency of $80 \%$, DCFC technology provides a powerful value proposition by permitting the realization of the nearly 160 -year-old dream of converting raw coal directly to electric power without combustion, gasification (reforming) or the thermal efficiency limitations of heat engines [3], combined with the possibility of reducing carbon emissions by $50 \%$ and reducing the off-gas volume by 10 times compared with conventional coalfired power stations $[4,5]$.

\subsection{US Army interest in DCFC development}

The U.S. military has increased its attention on energy policies [6] in recent years as mission capabilities are becoming more closely linked to energy consumption. The U.S. Army studied the potential for the DCFC to directly convert biomass-derived waste into

\footnotetext{
* Corresponding author. Tel.: +1 440460 2499; fax: +1 4404602478.

E-mail addresses: jruflin@gmail.com (J. Ruflin), aperwich@gmail.com (A.D. Perwich II)
}

electricity $[7,8]$. The development of such a technology could help to minimize the overall environmental impact and drastically reduce the burden of fuel transport for forward-operating military bases.

\subsection{DCFC technology}

The core technology for Contained Energy's DCFC was licensed under a Cooperative Research and Development Agreement (CRADA) with Lawrence Livermore National Laboratory (LLNL), and the LLNL results were the starting point of initial baseline experiments [9]. The DCFC concept is illustrated schematically in Fig. 1.

Oxygen reduced at the cathode combines with carbon dioxide to form a carbonate ion, which then passes through a molten carbonate electrolyte layer (consisting of a lithium carbonate and potassium carbonate eutectic) to react with solid carbon at the anode, forming carbon dioxide and electrons. Part of the anode carbon dioxide is re-circulated to the cathode. The overall net reaction is provided in Equation (1). The anode exhaust consists of pure, sequestration-ready carbon dioxide.

$\mathrm{C}+\mathrm{O}_{2}=\mathrm{CO}_{2}+$ electrical energy

\subsection{Expected efficiency}

The overall efficiency of any fuel cell is the product of a theoretical efficiency, fuel utilization efficiency, and voltage efficiency (see 


\section{Carbon Anode Filled with Electrolyle Cathode}

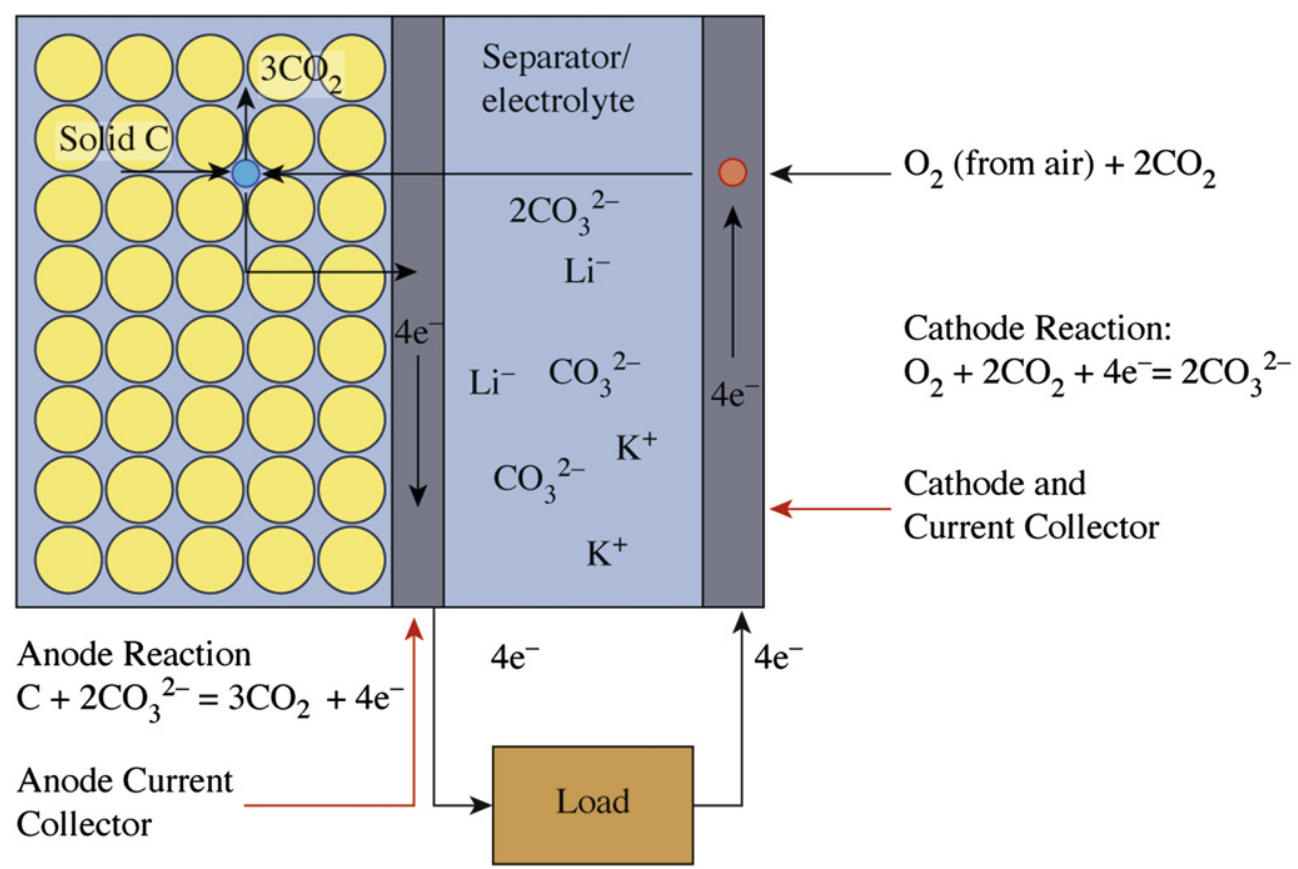

Fig. 1. Direct carbon fuel cell (DCFC).

Table 1). The theoretical efficiency is based on thermodynamics and is equal to $100.3 \%$ for the reaction of carbon at $750{ }^{\circ} \mathrm{C}$. Even compared with the theoretical efficiency for electrochemical conversion of other common fuels, the theoretical efficiency for carbon is high, which is why DCFCs have the potential to achieve efficiencies unattainable using most other technologies [3].

The voltage efficiency is a consequence of the chosen operating point. As an electronic load draws current from the fuel cell, the voltage of that cell drops. To achieve an efficiency of $80 \%$, the operating voltage must be no lower than approximately $0.8 \mathrm{~V}$ such that the voltage efficiency will be $80 \%$.

Fuel utilization efficiency is a measure of how much of the fuel entering the fuel cell is actually consumed by the electrochemical reaction. This number can vary substantially depending on the type of fuel cell and fuel used. In a fuel cell fed gaseous fuel derived from reforming a hydrocarbon, such as military jet fuel, this value typically does not exceed $80 \%$. That is, $20 \%$ of the fuel passes through the fuel cell without reacting. The utilization efficiency can be increased using pure hydrogen (which is less practical in a forward-

Table 1

Efficiency.

\begin{tabular}{lllll}
\hline \multicolumn{2}{l}{ Efficiency of fuel cells } & & \\
\hline Fuel Theoretical & Utilization & $V(i) /$ & Actual \\
& limit $=\Delta G^{\circ}(T) / \Delta H^{\circ}$ std \\
& & & & $\begin{array}{l}\text { efficiency }(\mu) \\
\text { efficiency }=(\Delta G / \\
\left.H_{\text {std }}\right)(\mu)\left(\varepsilon_{V}\right)\end{array}$ \\
\hline $\mathrm{C}$ & 1.003 & 1.0 & 0.80 & 0.80 \\
$\mathrm{CH}_{4}$ & 0.895 & 0.80 & 0.80 & 0.57 \\
$\mathrm{H}_{2}$ & 0.70 & 0.80 & 0.80 & 0.45 \\
\hline
\end{tabular}

Note: Efficiency of a fuel cell is defined as: (electrical energy out)/(heat of combustion (HHV) of fuels input) $=$ [theoretical efficiency $\Delta G / \Delta H$ ] [utilization fraction $\mu]$ [voltage efficiency $\left.\varepsilon_{V}\right]=\left[\Delta G(T) / \Delta H^{\circ}\right][\mu]\left[V / V^{\circ}\right]=[\mu][n F V] / \Delta H^{\circ}$ (where $\left.\Delta G(T)=-n F V^{\circ}=\Delta H-T \Delta S\right)$. deployed military application) or if fuel recycling mechanisms are employed; however, these modifications cause complications to and increase the cost of the fuel cell system. In a DCFC, no exit for the carbon exists; therefore, all the fuel should react and the fuel utilization efficiency should be $100 \%$.

In contrast to the theoretical and voltage efficiencies, the fuel utilization efficiency is more difficult to determine than locating it in a table or calculating it from the voltage of the cell. The fuel utilization efficiency, $\eta_{f}$, can be calculated using the following formula:

$$
\begin{aligned}
\eta_{f} & =\frac{\text { expected carbon consumption }}{\text { actual carbon consumption }} \\
& =\frac{\int \frac{M \cdot I \cdot \Delta t}{n \cdot F}}{\text { wt carbon fuel }- \text { wt carbon recovered }}
\end{aligned}
$$

where $I$ is the electric current, $t$ is the time of the electrochemical evaluation, $M$ is the molecular weight of carbon, $n$ is the number of electrons in the carbon reaction (which equals 4 ), and $F$ is Faraday's constant. The data required for this formula is the current output of the fuel cell over its operating life, the weight of the carbon fuel before operation, and the weight of the carbon fuel remaining after testing.

In the proposed DCFC design, the expected voltage was $0.6 \mathrm{~V}$, and thus, a cell efficiency near $60 \%$ was expected (the actual product development targets are discussed later in the paper).

\subsection{The importance of power density and efficiency}

Delivering viable products at a competitive cost remains a major commercialization challenge for all fuel cell technologies. To achieve commercialization, which is the goal of research and development (R\&D), products must compete on price, meet rigorous 
performance requirements and be reliable and durable. Early R\&D efforts must demonstrate performance characteristics compelling enough to attract resources to support longer term R\&D. To date, DCFC R\&D has not produced results that justify longer term support.

For a DCFC power system, both power density and efficiency are critical performance parameters. Power density is critical because it will dictate system size, portability, and cost. In certain applications, portability and volume requirements may not be primary drivers, but cost is a major concern in any application. Power density serves as a good proxy for cost because the lower the power density, the larger the size of the fuel cell system required to achieve a given power output. Manufacturing and material costs scale with fuel cell size; thus, the larger the fuel cell system becomes, the greater the material and manufacturing costs will be.

Efficiency is critical because it is the key metric that differentiates DCFC from other technologies. DCFC has the potential to far exceed the efficiencies of other technologies, including other fuel cells. However, if this efficiency cannot be achieved, then the DCFC will likely not be competitive with other fuel cell options due to the lower power density and larger size of the DCFC.

A DCFC demonstrating at least $120 \mathrm{~W} \mathrm{~L}^{-1}$ at $50 \%$ efficiency would justify further development of DCFC technology [10]. This value was the level of performance targeted by this work effort.

\section{Experimental setup}

Cylinder cells and half-cells were the main experimental platforms used during this work effort. Flat planar type cells were also produced; however, for basic research, the configuration in Fig. 2 proved to provide more cost effective and reliable results based on their inexpensive materials and simple standardized construction.

\subsection{Cylinder (gas) cell construction}

The basic cylinder cell construction is presented in Fig. 2. The cell assembly consists of two nickel foam electrodes pressed on each side of a zirconia cloth separator. Once wetted with electrolyte, the zirconia cloth separator provides both a route for ion transport and a gas barrier between the two electrodes. Screens are used on the outside of the foams to provide electronic connection to the electrodes and support the fuel cell structure. An alumina cylinder, placed on the top of the cell assembly, acts as an anode chamber and holds the carbon and electrolyte. The entire cell structure is compressed using flanges to ensure good contact between the layers (as shown on the left-hand side of Fig. 2). The side of the cylinder cell with the fuel cell assembly is placed in an oven to maintain the temperature; however, the top of the alumina tube is allowed to protrude from the top of the oven such that the cells can be reloaded while they are running. Inert gas is pumped into the top of the alumina tube to maintain a positive pressure in the anode chamber and ensure that oxygen does not enter and burn the carbon.

\subsection{Half-cell setup}

The half-cell setup used in the majority of efficiency experiments is presented in Fig. 3. A half-cell is a cell setup where one electrode is isolated and tested individually. Using a half-cell, the test results reflect only the performance of the anode because no cathode is present. The detail of the working electrode (WE) is illustrated on the left of the configuration, and the alumina crucible is shown on the right.

Fig. 4 shows the alumina tube with a section cut out and a porous alumina wall glued into place to act as the separator between the bed and the bulk electrolyte.
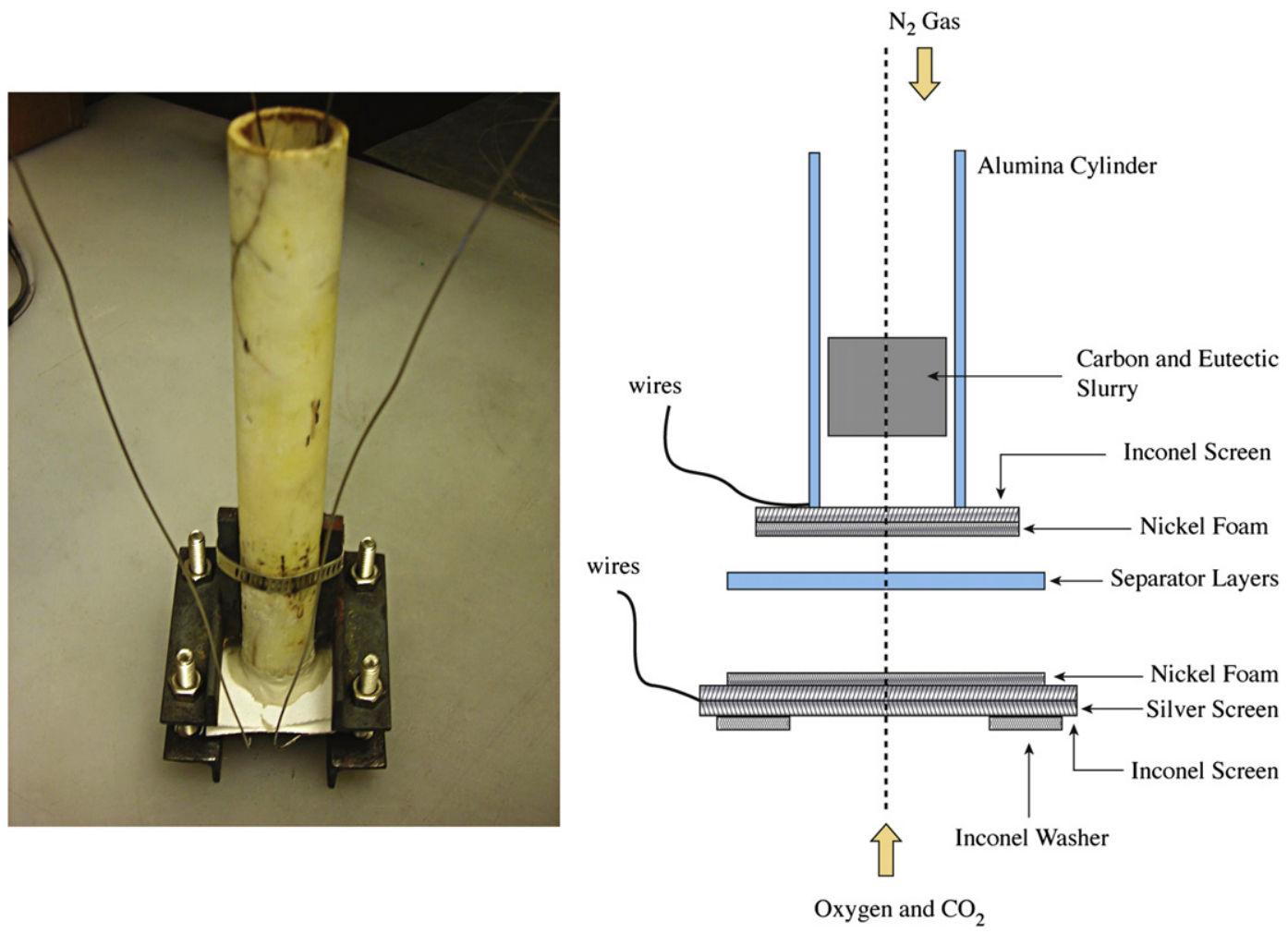

Fig. 2. Photo and schematic of the cylinder (gas) cell construction. 

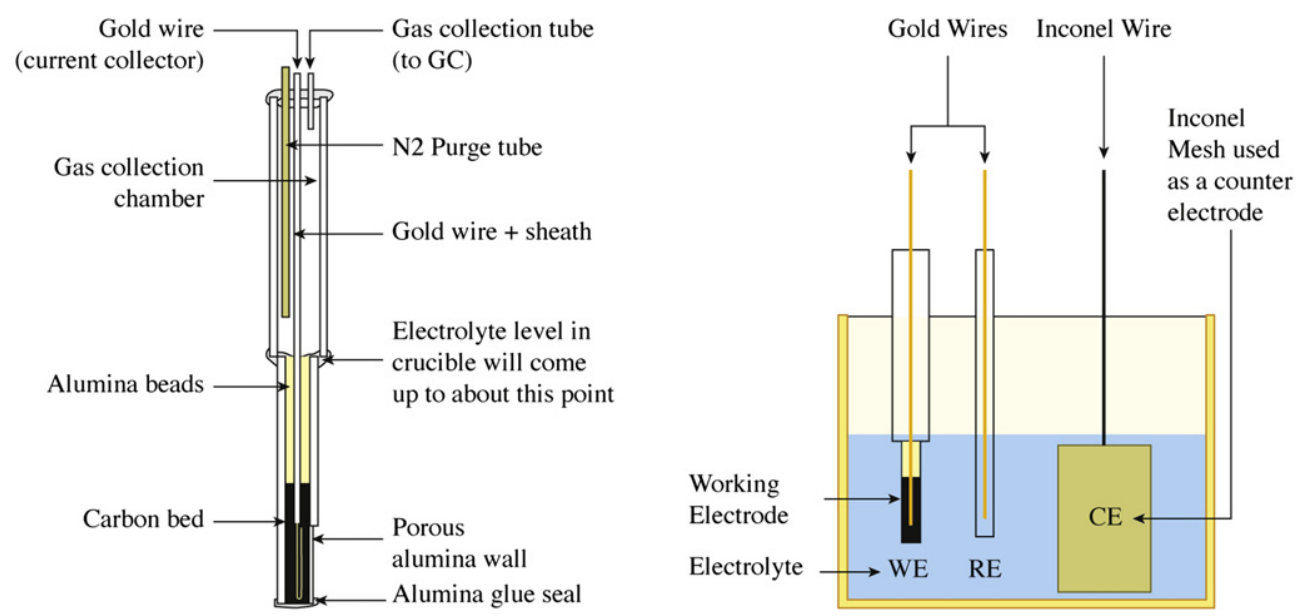

Fig. 3. Contained Energy's half-cell configuration employing a working electrode with a bed of carbon particles.

\subsection{Determining the weight of carbon}

The weight of the carbon fuel is easily measured before the experiment begins. The fuel was first dried to remove water that could otherwise affect the measurement; this step would not be necessary in actual DCFC systems. To determine the weight of the carbon at the end of the experiment, the carbon must be separated from the frozen molten carbonate also present in the anode chamber. The carbon and frozen molten carbonate recovered from the anode chamber were soaked in acetic acid and water to dissolve the molten carbonate. The mixture was then repeatedly washed, filtered, and finally dried to obtain an accurate measurement of the weight of the recovered carbon. An error estimate was determined for this carbon recovery process by testing on known mixtures of carbon and carbonate prepared in alumina crucibles under an inert atmosphere; the error estimate was found to be small enough to cause no more than $\pm 2 \%$ deviation in fuel efficiency measurements.

\subsection{Reverse Boudouard reaction cartridge test}

As the work plan developed, additional experimental set-ups were required, including an elegant experiment developed by Dr. Choong-Gon Lee to demonstrate the role of $\mathrm{CO}$ in the anode

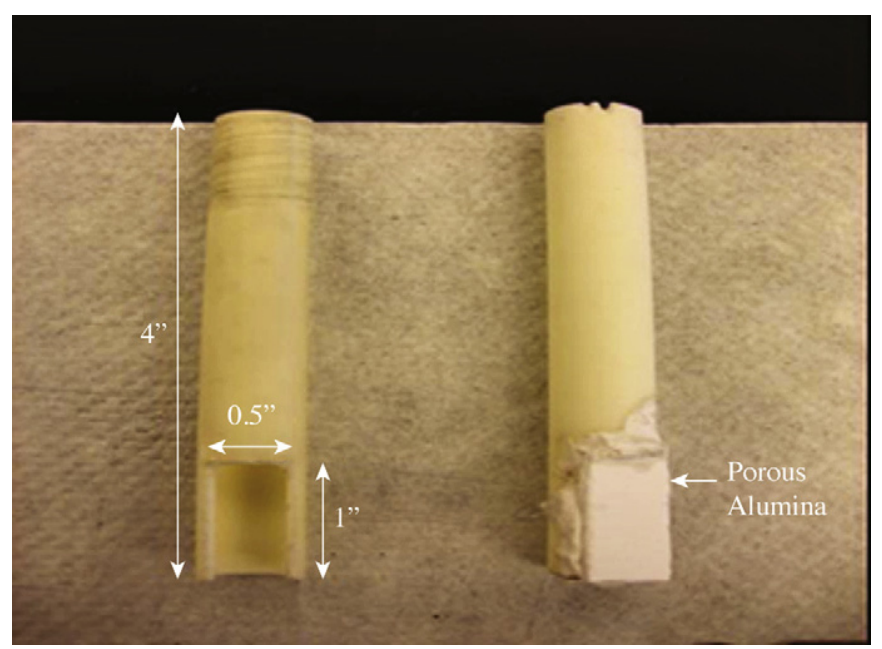

Fig. 4. Alumina tube and separator used for a carbon bed working electrode configuration. reaction [11]. Rather than directly dropping carbon into the anode chamber of the DCFC cylinder cell, as typically done, the carbon was contained within a separate alumina fuel cartridge (see Fig. 5). The cartridge consisted of an alumina tube with nickel foam inserted into both ends to ensure that the carbon and carbonate mixture could not reach the ends of the tube. The advantage of the cartridge was that it did not allow the carbon to touch the current collector in the anode chamber. If the carbon cannot touch the current collector, then it cannot react directly. That is, the only power that is produced by a cell using the cartridge must come from the reaction of gases indirectly, not directly from the carbon.

\section{Results and discussion}

\subsection{Power}

Early results proved promising, both in terms of voltage and power density (Fig. 6). Within the first six months, the cells at Contained Energy were able to consistently achieve twice the power output of the initial prototypes produced at the LLNL. The early Contained Energy results were also able to surpass our initial target of $180 \mathrm{~mW} \mathrm{~cm} \mathrm{~cm}^{-2}$, which we believed was the minimum power output necessary to produce a viable product for military unmanned ground vehicle applications. The problem that these cells had, however, was that the efficiency was lower than expected.

\subsection{Efficiency results and the reverse Boudouard reaction}

In the initial tests of DCFC efficiency, the fuel cells were run at $0.6 \mathrm{~V}$, and thus, the expected efficiency was approximately $60 \%$. However, the initial results were well below the expected $60 \%$ and varied as a result of the fuel source (see Table 2). Because the theoretical efficiency of a DCFC is $100.3 \%$ [3] and voltage efficiency can be readily measured (and in this case should be approximately $60 \%$ ), the low values recorded were likely a result of the fuel utilization efficiency. Rather than producing electricity in the fuel cell, the carbon fuel was being consumed by another reaction.

The initial explanation for the low measured efficiency was an oxygen leak in the test apparatus. The hypothesis was that oxygen was leaking into the fuel chamber and reacting with the carbon before the fuel had time to produce power in the fuel cell. As efficiency tests continued, however, several of the experiments produced data that were inconsistent with the oxygen leak explanation. If the low efficiency was due to an oxygen leak, then the leak 


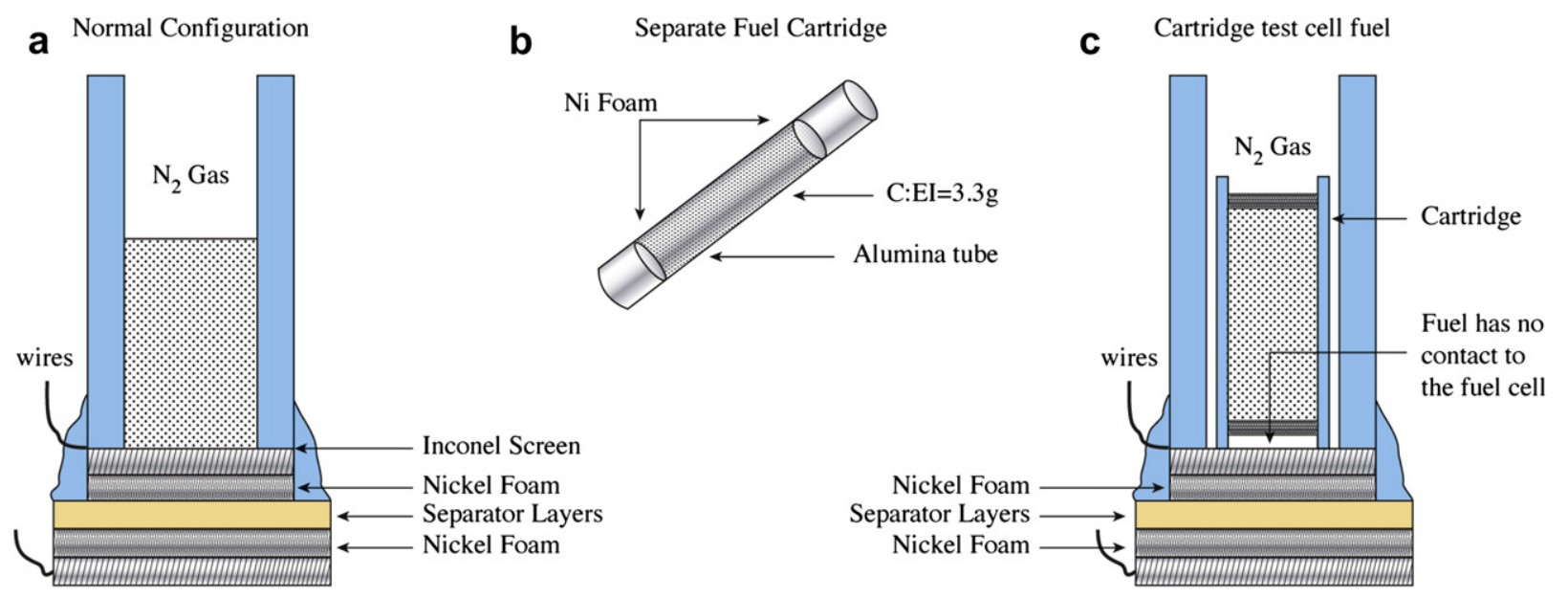

Fig. 5. Cartridge cell.

should remain roughly constant whether the cell is producing power or idle.

However, the leak rate (carbon lost per hour) was observed to be much greater for cells that were "on" and producing power for long periods of time than for cells that were primarily idle over their lifetimes; this result seemed to indicate that the fuel cell reaction itself was somehow increasing the leak rate and consequently reducing efficiency. Note that the leak rate in a cell was calculated by determining how much carbon was lost per hour that could not be attributed to the electrochemical reaction taking place to produce current in the fuel cell.

Additional testing, including off-gas measurements, confirmed that in addition to oxygen leaks, the reverse Boudouard reaction was hypothesized as a possible contributor to the low efficiency of the DCFC.

The preferred DCFC reactions are noted in Fig. 7. Ideally, the anode reaction results in pure $\mathrm{CO}_{2}$ that does not react with any other products. However, the anode off-gas measurements indicated the presence of carbon monoxide (CO), an undesired output. The $\mathrm{CO}$ in the fuel cell resulted from the reverse Boudouard reaction:

$\mathrm{CO}_{2}+\mathrm{C} \rightarrow 2 \mathrm{CO}$

whereby the unused carbon fuel in the anode chamber reacts with the $\mathrm{CO}_{2}$ off-gas produced in the electrochemical reaction to

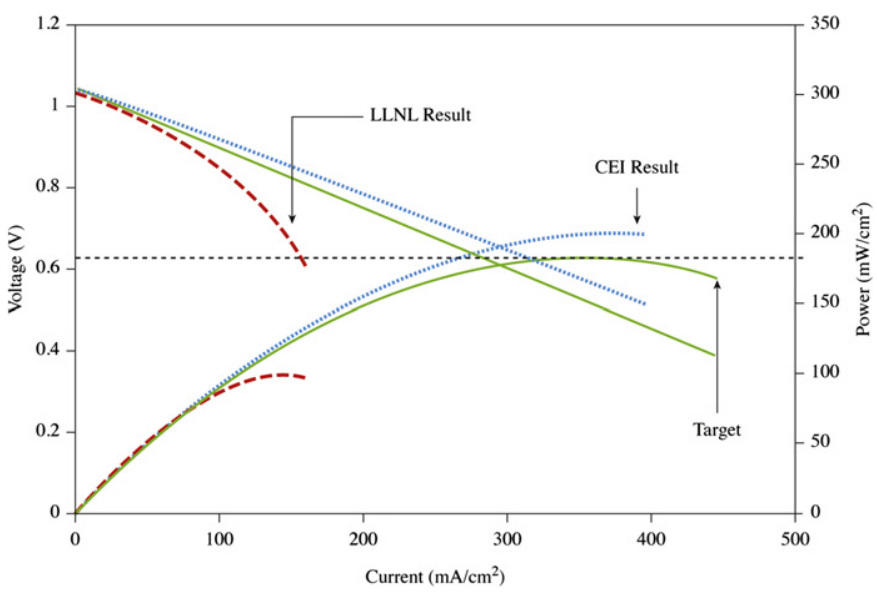

Fig. 6. Early results - power. produce carbon monoxide, which then exits the cell; when the reverse Boudouard reaction (see Fig. 8) occurs, the $\mathrm{CO}_{2}$ on its way out of the fuel cell essentially picks up carbon fuel and carries it out as well (in the form of $\mathrm{CO}$ ). The carbon reacting with the $\mathrm{CO}_{2}$ has no opportunity to produce power, which consequently reduces the fuel utilization efficiency of the DCFC.

The reverse Boudouard reaction expresses an equilibrium condition and, provided sufficient time, determines the percent of $\mathrm{CO}$ and $\mathrm{CO}_{2}$ gas in the presence of carbon. As Fig. 8 illustrates, the equilibrium favors $\mathrm{CO}$ at the operating temperatures of the DCFC $\left(750-850^{\circ} \mathrm{C}\right)$. The reverse Boudouard reaction is typically sluggish; however, the molten carbonate electrolyte (i.e., the "eutectic" in Fig. 7) serves as a catalyst for the reaction. The reverse Boudouard reaction in the presence of the carbonate electrolyte is sufficiently fast to have the potential to negatively and severely impact the fuel cell efficiency. If high efficiency of the DCFC is to be achieved, the reverse Boudouard reaction must be eliminated from the anode chamber of the fuel cell.

Simply decreasing the temperature did not resolve the issue with the reverse Boudouard reaction, as decreasing the temperature resulted in a decrease in power output (see Fig. 9).

\subsection{Effect of reverse Boudouard reaction on power output}

The presence of $\mathrm{CO}$ in the anode also raised the concern of the role that $\mathrm{CO}$ might play in the electrochemical reaction. Carbon must react directly in the DCFC to ensure a high fuel utilization efficiency. The fuel utilization efficiency of the DCFC can be $100 \%$ in theory because the carbon is solid. If instead, a gas such as $\mathrm{CO}$ is reacting and producing the majority of power, then fuel utilization efficiency anywhere near $100 \%$ will not be achievable. In fact, the DCFC would be worse than a typical fuel cell because it is not designed to operate on a gaseous reactant.

Cartridge test results indicated that the DCFC was running almost entirely on the CO produced by the reverse Boudouard reaction rather than on the carbon fuel directly. The performance of

Table 2

Results of selected fuel efficiency tests.

\begin{tabular}{ll}
\hline Fuel & Average efficiency \\
\hline Crushed graphite & $24.4 \%$ \\
Coconut shell charcoal (made in-house) & $20.5 \%$ \\
Coconut shell charcoal (bought from Kamado) & $22.4 \%$ \\
\hline
\end{tabular}

Note: Kamado coconut shell charcoal bought from Komodo Kamado, Bali, Indonesia. 


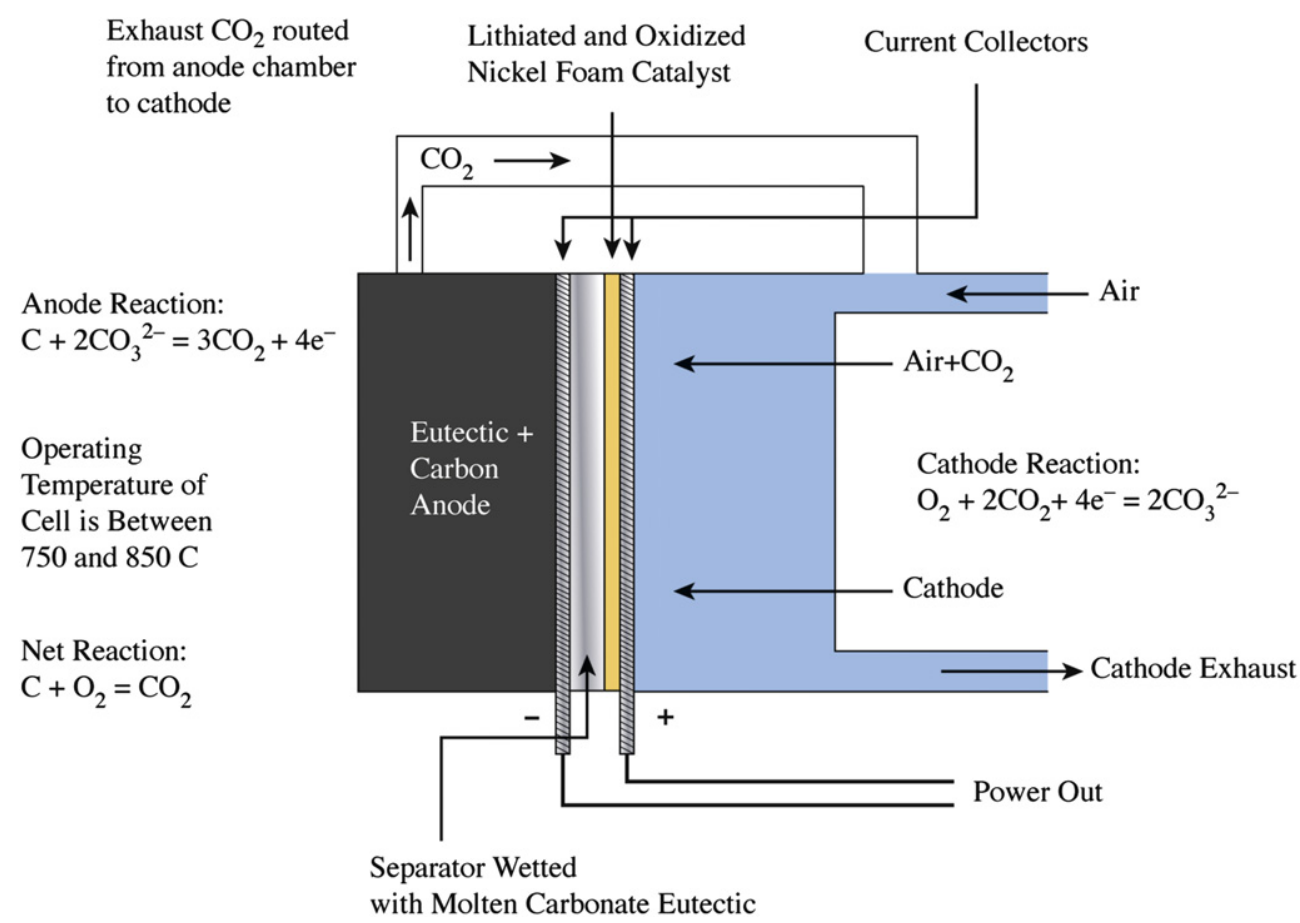

Fig. 7. Direct carbon fuel cell.

cylinder cells utilizing fuel cartridges was identical to the performance of cylinder cells that were fed carbon without the cartridge. Thus direct contact between the current collector and the carbon fuel was unnecessary since both cylinder cells with and without fuel cartridges were running on carbon monoxide rather than carbon. These results indicate that the high power densities achieved in early tests, such as those shown in Fig. 6, were also a result of the cells running on carbon monoxide.

\subsection{Redesign of the DCFC and improvement of polarization}

Based on the results of the efficiency investigation, the operating temperature of the fuel cell was dropped from $850{ }^{\circ} \mathrm{C}$ to $750{ }^{\circ} \mathrm{C}$ because the rate of the reverse Boudouard reaction and the equilibrium ratio of $\mathrm{CO}$ to $\mathrm{CO}_{2}$ both increase with temperature (as previously noted in Fig. 8). Redesigning the cell to improve polarization was also undertaken in an attempt to eliminate the reverse

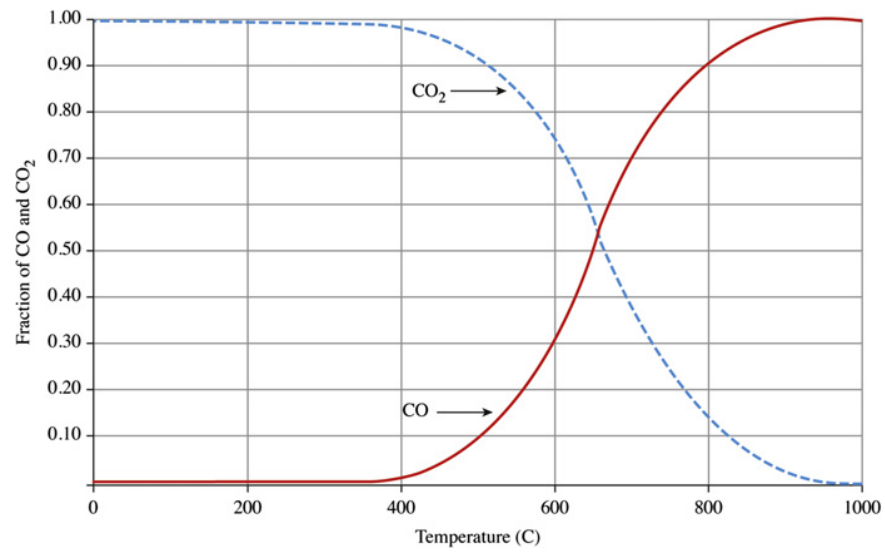

Fig. 8. Reverse Boudouard reaction.
Boudouard reaction and force the cell to run directly on carbon rather than on $\mathrm{CO}$.

Past literature on DCFCs has in fact demonstrated that at very low overpotentials, DCFCs will produce $\mathrm{CO}$ rather than $\mathrm{CO}_{2}$. Thus, in general, sufficient polarization is a desired condition in the anode chamber, as polarization has the capability to protect the carbon fuel from the reverse Boudouard reaction $[12,13]$.

The half-cell experiments in the literature indicate that if polarization is sufficient, the carbon will only produce $\mathrm{CO}_{2}$, and the reverse Boudouard reaction can be prevented, even if the reverse Boudouard reaction is otherwise favored at the given temperature. The results of the early literature studies provided a reason to continue pursuing DCFC technology; otherwise, without being able to stop the reverse Boudouard reaction, the DCFC would have low efficiency and little commercial value [14].

Cooper et al. suggested that the reverse Boudouard reaction could be excluded from the DCFC at practical temperatures (an

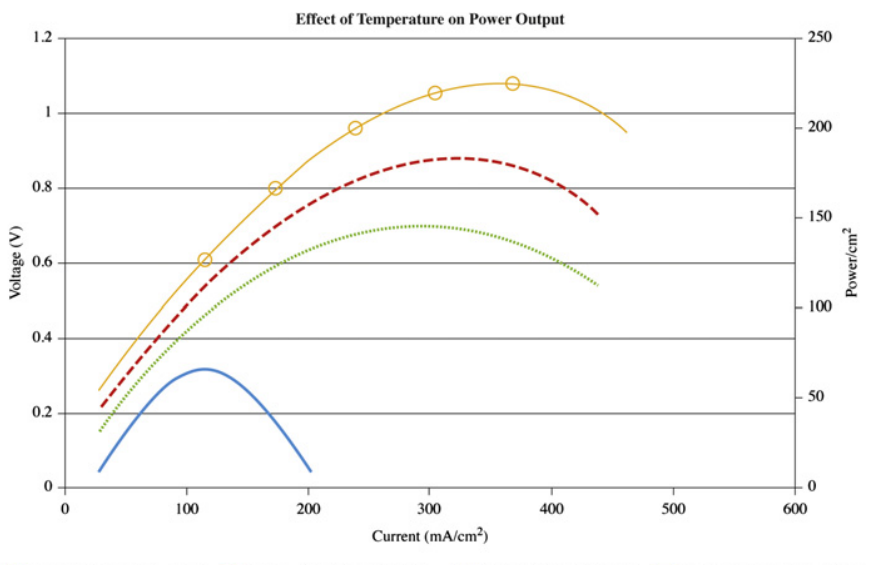

- $850 \mathrm{C}$ - Experiment - $1000 \quad--800 \mathrm{C}$ - Experiment CC461 ……750 C-Experiment $616-650 \mathrm{C}$ - Experiment CC549

Fig. 9. Effect of temperature on power. 
operating temperature greater than $650{ }^{\circ} \mathrm{C}$ ) with an operating potential of approximately $0.8 \mathrm{~V}$ or less per cell [15]. At this polarization, the understanding was that all of the carbon fuel would be electrochemically converted to $\mathrm{CO}_{2}$ and electrons, and the reverse Boudouard reaction would not occur.

To ensure sufficient polarization, the surfaces of all carbon particles exposed to $\mathrm{CO}_{2}$ in the anode compartment of a working cell must be in good contact with the molten carbonate, which conducts the ions. The carbon particles must also have good contact with other carbon particles in the bed and with the current collector in the anode to ensure that the carbon has sufficient access to electrons. If either the ionic or electron-conducting pathways are poor, the carbon may not be able to react, and if the carbon is not reacting, then it is susceptible to the reverse Boudouard reaction.

Experiments have demonstrated that sufficient polarization in a carefully controlled experiment, such as that used in the literature, is not difficult to achieve. The experiments in the past literature were specifically designed to ensure that the reacting carbon surface was well connected electrically and has excellent access to the electrolyte (conditions necessary for polarization); all exposed surfaces of carbon reacted electrochemically and at high enough currents that they achieved sufficient polarization. For instance, using a solid slug of carbon, such as graphite, fuel utilization efficiencies of approximately 95\% were obtained in the half-cell experiments. For controlled experiments where a slug was used (the carbon slug was tied to a gold wire and immersed in the electrolyte of the half-cell experiment), the high efficiencies consistent with the literature were achievable.

In contrast, polarization in an anode chamber consisting of loose carbon particles is much more difficult to achieve. For practical commercial applications (e.g., a forward-deployed military generator), using a slug of carbon appears impractical if the carbon is being derived from waste or from pyrolysis of a liquid fuel. The carbon powder produced by pyrolysis of waste or fuel would need to be pelletized into large blocks of carbon before being fed into the fuel cell. This pelletization process would not only require additional auxiliary equipment and cost but also likely make reloading of the fuel cell difficult. Therefore, focused efforts were placed on achieving polarization and thus a high efficiency in a DCFC capable of running on loose carbon.

Fuel utilization efficiencies as high as $80 \%$ with beds of carbon particles were achieved, with the average result being $68 \%$. These results were much better than the fuel utilization efficiencies originally measured but not sufficient for the final product.

None of the many polarization experiments significantly increased the fuel utilization efficiency beyond approximately $80 \%$. Sufficient polarization within the bed of carbon may not have been achieved, and another method may generate better results. However, results from an extensive number of tests raise the concern that polarization might not be able to protect loose carbon. The carbon bed is moving and shifting continuously due to bubble generation, which can cause disconnects of the carbon and make sustaining polarization difficult. The shifting of the bed, the high surface area, and the easy access to $\mathrm{CO}_{2}$ bubbles also improves mass transport, which can promote the reverse Boudouard reaction, thus decreasing the cell efficiency. At the conclusion of this study, achieving sufficient efficiency continued to remain a challenge.

\subsection{Power density}

The target power density for the DCFC in this study was $120 \mathrm{~W} \mathrm{~L}^{-1}$ (or $120 \mathrm{~W} \mathrm{~cm}^{-2}$, assuming a 1 -cm-thick cell) at $50 \%$ efficiency. The original DCFC test cells running at $850{ }^{\circ} \mathrm{C}$ were able to achieve the power density target of $120 \mathrm{~W} \mathrm{~L}^{-1}$ but could not achieve the $50 \%$ efficiency because of the reverse Boudouard reaction. Despite many efforts to improve the efficiency (e.g., lowering the temperature, cell design modifications and efforts to improve polarization), a significant reduction in power density to approximately $20 \mathrm{~W} \mathrm{~L}^{-1}$ occurred.

A DCFC with a power density of $20 \mathrm{~W} \mathrm{~L}^{-1}$ would be over ten times larger than an MCFC stack that can produce the same power output. Because manufacturing costs increase with stack volume, the current DCFC technology would be substantially more expensive and to a degree that cannot be overcome by the value of its fuel and efficiency benefits.

To improve the power density, efforts were focused on the anode because half-cell experiments and the use of reference electrodes in complete cells clearly indicated that the anode was primarily responsible for the poor DCFC performance observed.

The four factors that dictate anode performance (and in fact electrode performance in any cell) are

1. Ohmic resistance: a measure of the resistance to the flow of current in the cell;

2. Kinetics: dictates the speed of the electrochemical reaction;

3. Mass transport: moves reactants and products to and from the reaction sites; and

4. Active area: how much of the electrode is actually participating in the reaction.

The goal was to determine which of these factors caused the poor performance in the anode of the DCFC and then, if possible, to solve the problem.

\subsection{Ohmic resistance and active area}

The ohmic resistance is a measure of both the electronic and ionic conductivity within the fuel cell. The electronic conductivity is affected by the number and conductivity of the carbon particles within the bed, the connection between the particles, and the connection of the particles to the current collector. The ionic resistance is affected by the conductivity of the electrolyte, the amount of electrolyte present, and the path length through the electrolyte that the ions must travel to reach the reaction site.

The results of AC impedance indicated that the ohmic resistance in the DCFC is no more than approximately $5 \%$ of the total resistance of the cell. That is, the ohmic resistance does not seem to cause the low performance of the DCFC. Note, however, that the AC impedance method only measures the resistance of the portion of the cell that is actively involved in the circuit being tested. For example, the electrolyte could actually be a very poor conductor, but its high resistance may not appear in the AC impedance measurement because the current only remains in the electrolyte for a very short distance. This situation is depicted using the resistance network presented in Fig. 10, which is meant to represent the current as it travels through the carbon bed (as illustrated by the current flowing from left to right). $R_{\mathrm{C}}$ is the resistance per unit of bed to the flow of current within the carbon, and $R_{\mathrm{E}}$ is the resistance per unit of the electrolyte. As the current travels from left to right, it can travel through the carbon (Fig. 10a) or through the electrolyte (Fig. 10b). At any point in the bed, the current can jump from the electrolyte to the carbon by reacting, in which case the current must go through $R_{\mathrm{CT}}$ (the charge transfer resistance).

Ideally, the current would travel throughout the bed as shown in Fig. 10a; in this case, the current is transferring from the electrolyte to the carbon at all points in the bed, and $100 \%$ of the carbon is considered to be active (or polarized). The concern is that a situation, such as that is depicted in Fig. 10b, occurs instead, i.e., the current only travels a short distance through the available electrolyte because of the large resistances in the electrolyte, quickly 

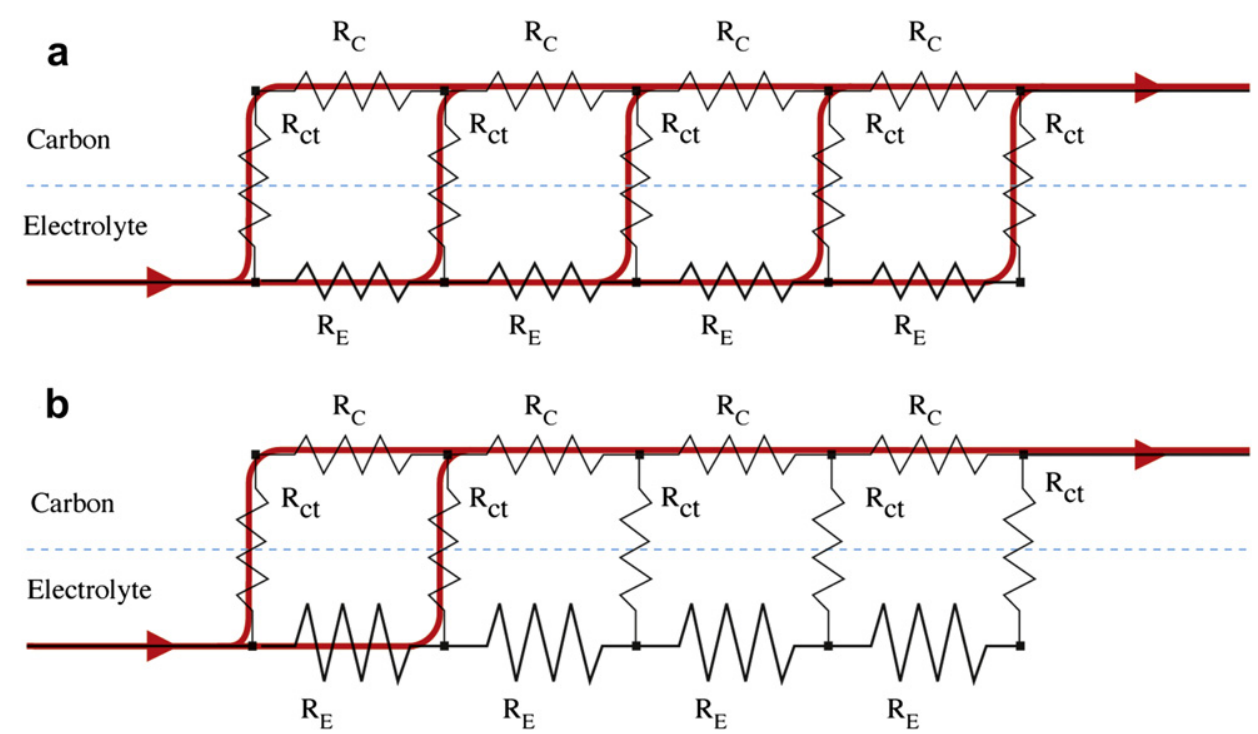

Fig. 10. Circuit diagram to represent current flow through the carbon bed of the fuel cell.

jumps to the relatively lower resistance carbon and completes its travel. In Fig. 10b, only approximately $40 \%$ of the bed (as depicted) is active, which implies that $60 \%$ of the bed is not being utilized. This low active area results in poor utilization of the carbon surface area and low polarization, both of which result in decreased power.

Because the current quickly jumps from the electrolyte to the carbon, the AC impedance measurement techniques may not accurately measure the ohmic resistance of the electrolyte because only a small portion of the circuit (the first resistor in Fig. 10b) is part of the active circuit measurement.

These results indicate that the ohmic resistance and active area of the electrode are not the factors limiting performance and that the carbon bed is mostly active and participating in the electrochemical reaction. Therefore, the performance problems experienced were likely due to kinetics and/or mass transport.

\subsection{Kinetics and mass transport}

Several of the tests indicated that kinetic resistance was a problem. The dramatic improvement in the performance of the half-cells with fuel cell operating temperature indicated

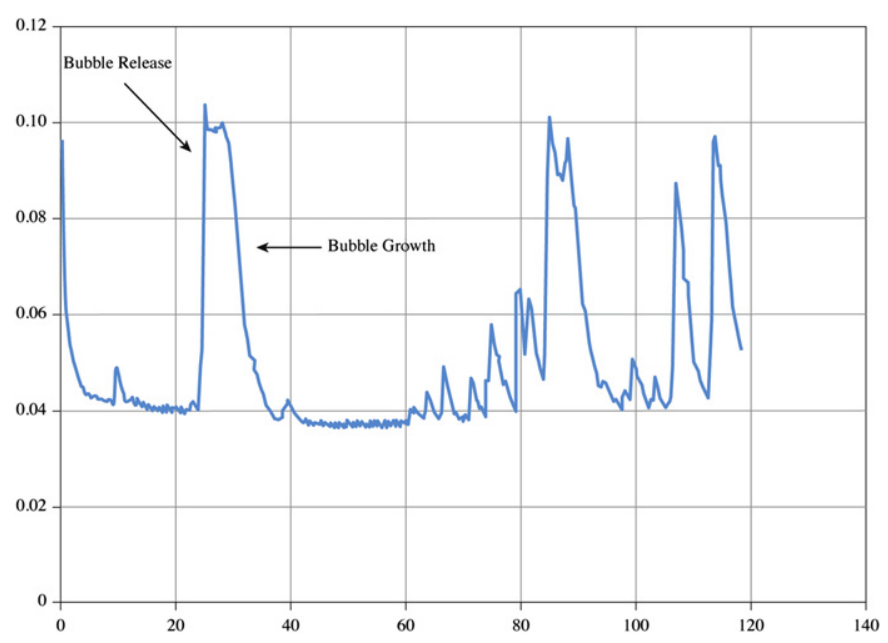

Fig. 11. Effect of bubbles on fuel cell performance. a significant kinetic resistance. The tests with $\mathrm{AC}$ impedance also indicated that kinetic resistance was very high and likely accounted for at least $60-70 \%$ of the overall half-cell resistance.

In an attempt to improve the kinetics, catalysts were added to the electrolyte. However, solid catalysts, such as gold, nickel, and platinum powder, did not provide significant improvement, probably because of the distributed nature of the carbon bed and the consequently low contact with the catalyst particles. These catalysts would probably also be prohibitively costly to implement. A liquid catalyst was also considered but ultimately ruled out due to the inability to identify any modifier that could be liquid in the cell at the operating temperature and produce substantially more power than that already achieved (the existing electrolyte was the effective catalyst of choice for increasing the rate of the carbon oxidation reaction).

Mass transport was also an issue. In early tests using audio and visual recording techniques, the effect of bubble growth on fuel cell performance was observed. As demonstrated in Fig. 11, bubbles can have a dramatic impact on the performance of the cell.

Tests were conducted using agitation techniques to attempt to improve the mass transport of the fuel cell. Agitation techniques,

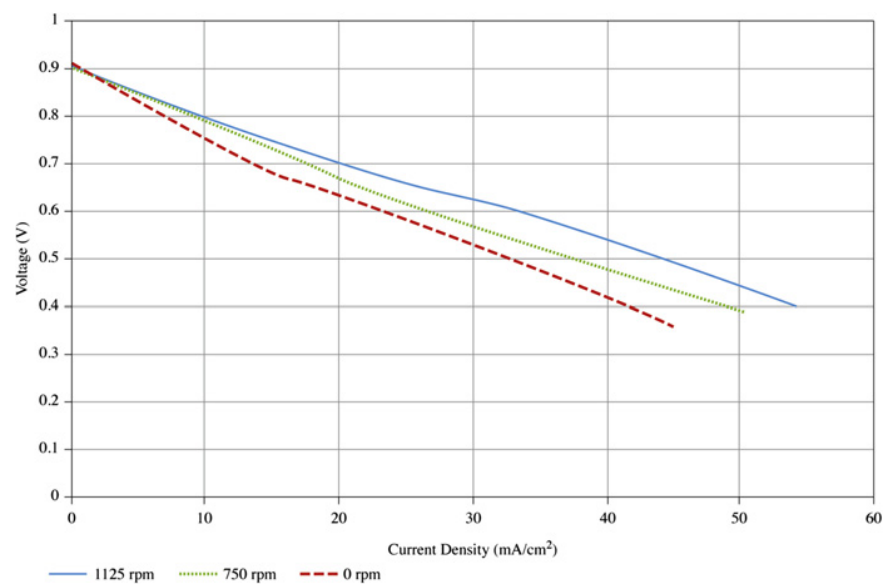

Fig. 12. Voltage-current curves for a carbon bed half-cell stirred at various speeds by an alumina paddle. 


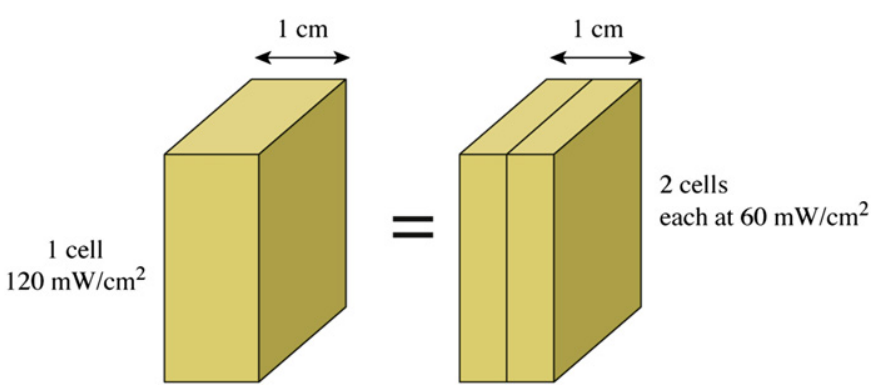

Fig. 13. Two configurations that achieve the same power per volume with different power per area.

particularly bubbling gas through the bed or vigorously stirring the carbon in the bed, produced modest improvements in performance. The results in Fig. 12 are for a DCFC half-cell that was a stirred by an alumina paddle at the speeds indicated in the figure.

However, the modest gains that the agitation techniques provided did not justify the complication of adding the agitation mechanism to the cell.

\section{Hybrid electrode DCFC}

\subsection{Overview}

Given the aforementioned results, improving the power per unit area of the electrodes would be difficult. However, an alternate method to maintain volumetric power levels was pursued by fitting more cells into a given space to achieve the proposed target of $120 \mathrm{~W} \mathrm{~L}^{-1}$. The original objective was to achieve $120 \mathrm{~mW} \mathrm{~cm}^{-2}$ in a $1-\mathrm{cm}$-thick cell. If the cell was only $0.5 \mathrm{~cm}$ thick, however, then the power requirement would only be $60 \mathrm{~mW} \mathrm{~cm}^{-2}$ to still achieve $120 \mathrm{~W} \mathrm{~L}^{-1}$ (as demonstrated in Fig. 13).

To thin the cells, a hybrid electrode DCFC design was created that incorporated components of a solid oxide fuel cell (SOFC) technology [16] that was developed by NASA. This particular SOFC technology has the unique characteristic of being planar in design but having extremely thin cells compared with other SOFCs.

The developed DCFC design was considered a hybrid electrode configuration because it utilized components from both SOFC and MCFC technology [17].

The backbone of the SOFC design was a porous ceramic structure composed of yttria-stabilized zirconia (YSZ) called the scaffolding [18]. The scaffolding was fabricated using a ceramic freeze-casting method, which creates hollow, unidirectional channels through a sheet of yttria-stabilized zirconia (YSZ). These channels were used for transporting air to the cathode reaction sites. A schematic of the SOFC is presented in Fig. 14.

By creating micro gas channels throughout the scaffolding rather than building them into a traditional interconnect (as is common with many planar SOFCs), the entire YSZ scaffolding structure, including the channels for gas flow, was approximately $250 \mu \mathrm{m}$ thick for a single electrode, resulting in a significant increase in specific power over state-of-the-art SOFCs. Fig. 15 shows a gas channel of $1200 \mu \mathrm{m}$ : during this study, NASA was able to reduce the micro gas channels to approximately $250 \mu \mathrm{m}$.

In the SOFC design, the layers of scaffolding were then stacked, and different catalysts were deposited in each layer to create alternating cathodes and anodes. In contrast, the design presented in Fig. 16 uses only one layer of scaffolding per cell. In place of the anode scaffolding, a box-like structure composed of YSZ (the same material as the scaffolding ceramic) was used to create the anode chamber and contain the carbon.

A dense, thin YSZ electrolyte layer was deposited between the cathode scaffolding and the anode chamber and conducted the oxygen ions from the cathode to the anode chamber similarly to a typical YSZ-based electrolyte in an SOFC. This layer also served as a barrier, preventing the molten carbonate electrolyte from moving from the anode to the cathode. Because both the anode structure (the YSZ electrolyte layer) and the anode were composed of the same material, the layers were constructed together in the green form and then fired together, resulting in a single integrated structure.

A layer of a high temperature, electron-conductive ceramic, such as lanthanum chromite, was added to the top of the scaffolding of each cell, and a set of adjoining cells were electrically connected
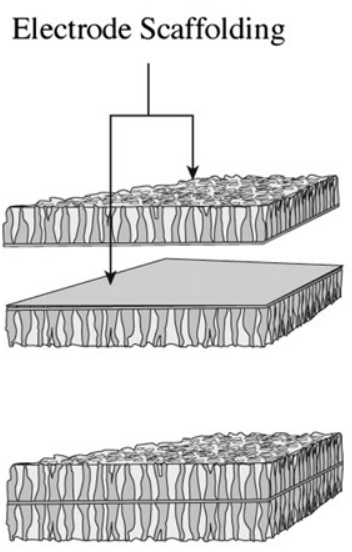

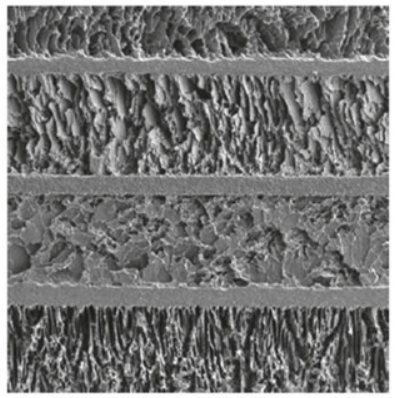

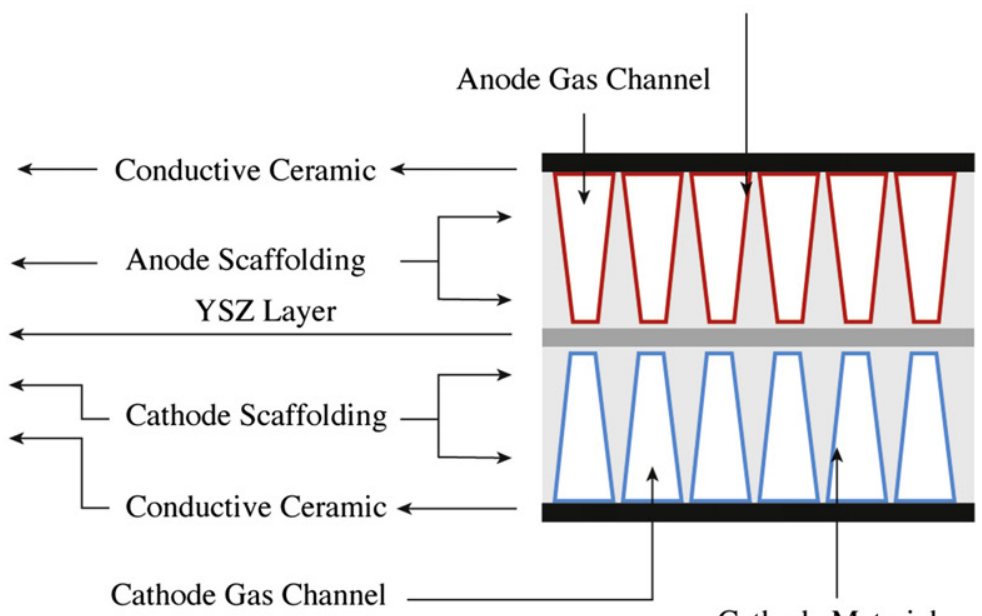

Anode Material

Cathode Material, doped $\mathrm{LaMnO} 3$

Fig. 14. Depiction of the solid oxide fuel cell technology. 


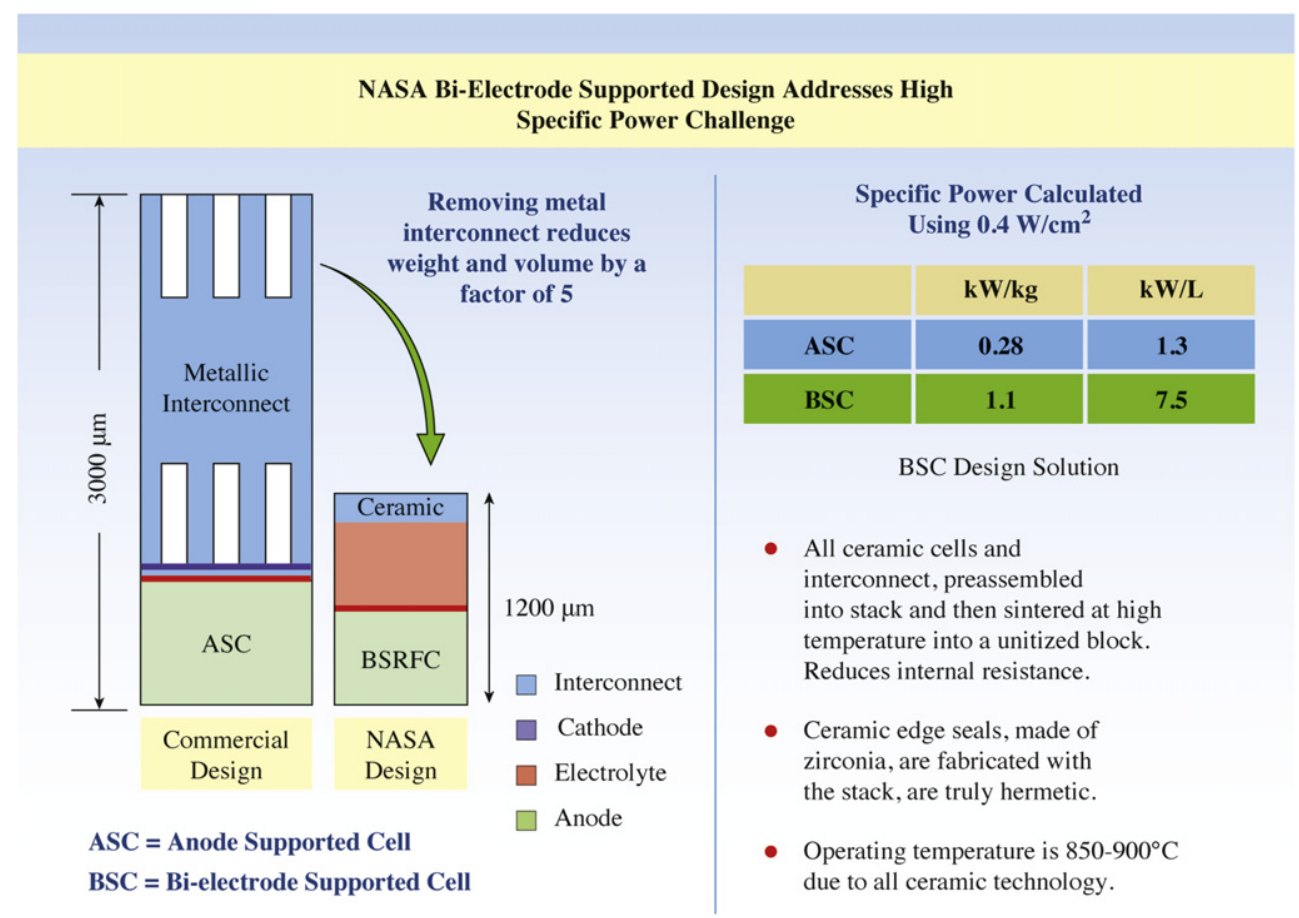

Fig. 15. NASA BSC design. Source: February 2009 presentation by NASA GRC SOFC Team to Contained Energy.

using a series connection. The single cell structure shown in Fig. 16 could then be repeated by laminating single-cell structures together to create one solid stack of any number of cells.

A common SOFC electrode material (e.g., lanthanum strontium manganite with a perovskite crystal structure, LSM) was deposited using a proprietary infiltration method onto the surface of the channels on the cathode side to impart the catalytic properties necessary to catalyze the oxygen reaction. The molten carbonate electrolyte was contained in the anode chamber to improve electrolyte/carbon contact and enhance ion transport.

The electrons generated in the anode travel through the electrode coatings and through the conductive ceramic onto the next cell in the stack. At the ends of the stack, the electrons travel through an external circuit and an applied load before returning back to the other side of the fuel cell. Fig. 17 indicates the pathways for a single cell DCFC hybrid electrode design.
Fig. 17 depicts the reaction as $\mathrm{O}^{2-}$ reacts with carbon, although the actual mechanism could be more complicated. The reactions depicted in Fig. 17 are given as

Cathode reaction : $\quad \mathrm{O}_{2}+4 \mathrm{e}-=2 \mathrm{O}^{2-}$

Anode reaction : $\quad \mathrm{C}+2 \mathrm{O}^{2-}=\mathrm{CO}_{2}+4 \mathrm{e}^{-}$

Complete reaction: $\quad \mathrm{C}+\mathrm{O}_{2}=\mathrm{CO}_{2}$

\subsection{Construction and initial performance}

To create the button cell, one layer of scaffolding was laminated onto a thin layer of YSZ, which served as the electrolyte layer. The

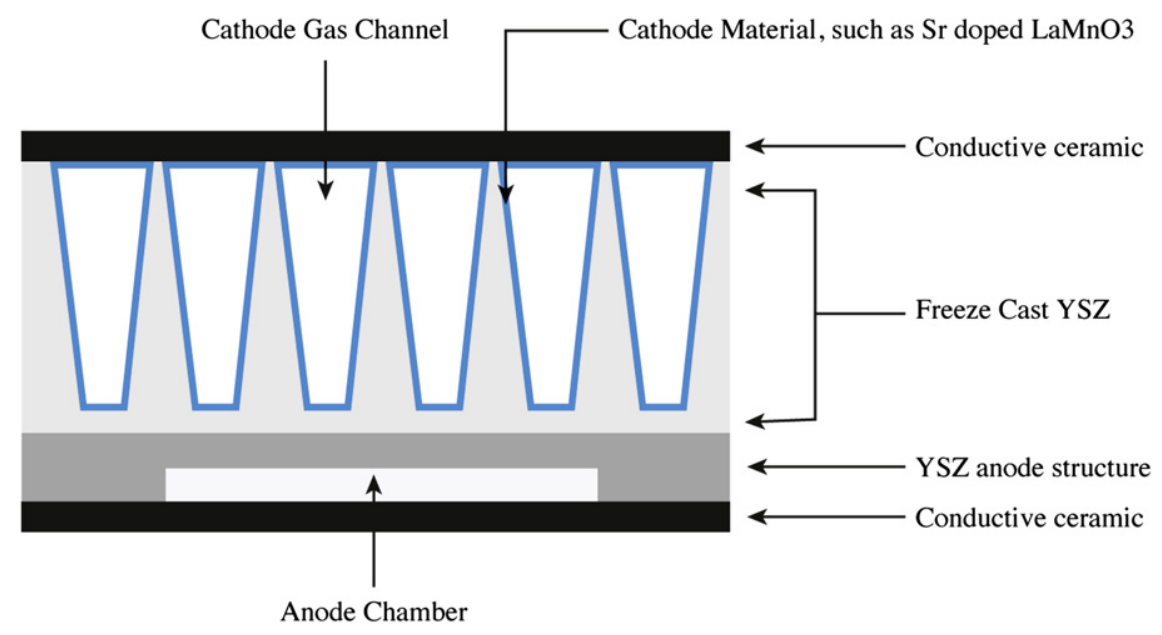

Fig. 16. Proposed DCFC concept. 


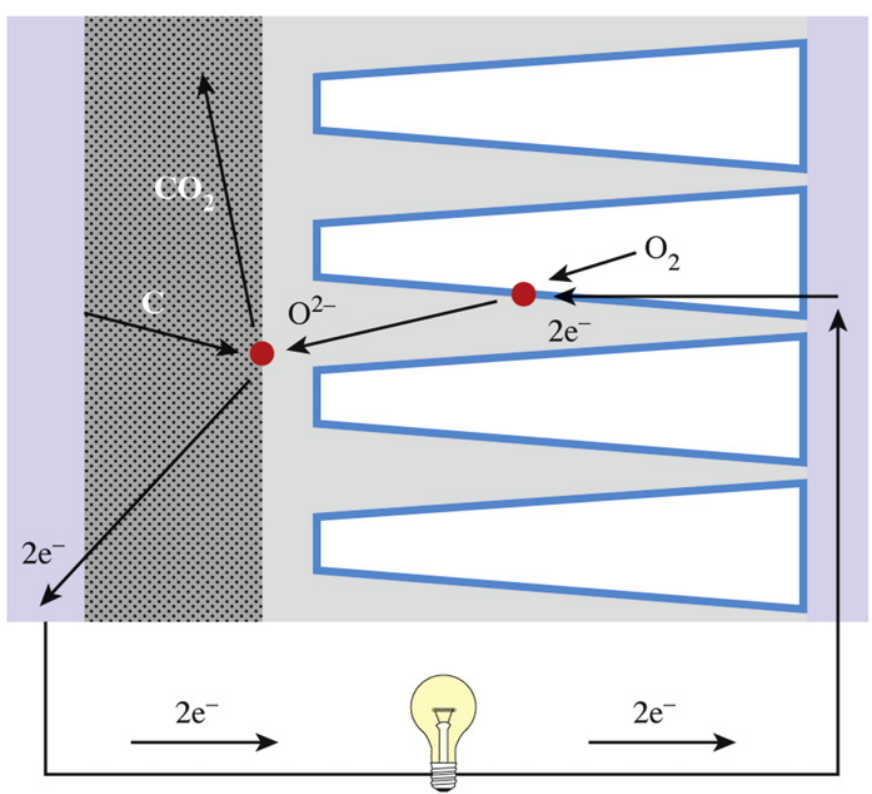

Fig. 17. Electron and ion pathways in the DCFC hybrid electrode design.

cathode catalyst material was then added to the structure, and the resulting button was bonded onto the bottom of a high-density alumina tube (refer to Fig. 18). Voltage and current leads were then attached, carbon and the electrolyte were added to the anode chamber, and the cell was placed into an oven for testing. All tests were performed at $750^{\circ} \mathrm{C}$.
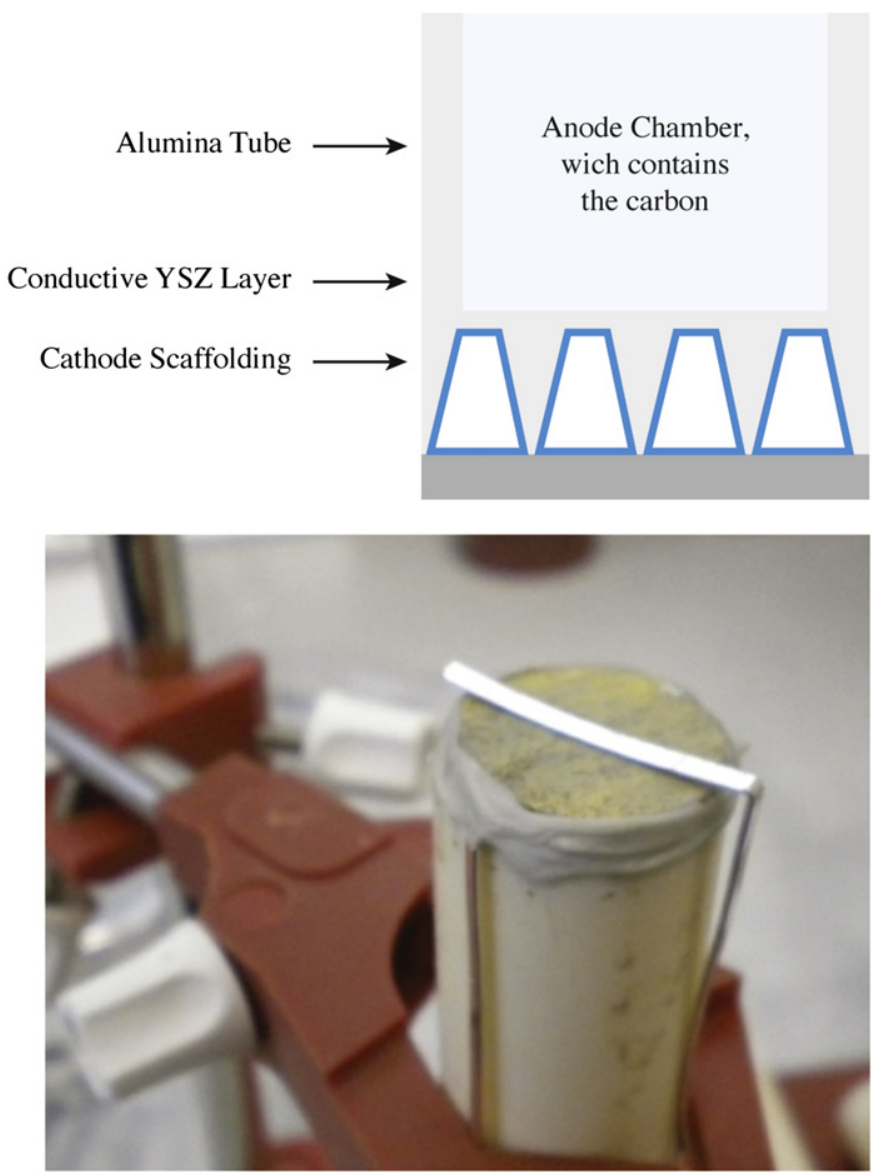

Fig. 18. Button cell being assembled for testing.
Several hybrid electrode cells were built and tested. The performance of these cells tended to be lower than the performance of the DCFC half-cells. The hybrid electrode cells were only able to achieve approximately $10 \mathrm{~mW} \mathrm{~cm}^{-2}$ at $750{ }^{\circ} \mathrm{C}$. The low performance was likely due to molten carbonate leaking through the seals used to attach the alumina tube to the hybrid electrode DCFC button cell. Visible leakage was observed in many of the cells along with indications that the molten carbonate then reacted with the cathode and current collector materials once the cathode was reached. These chemical reactions are presumed to have adversely affected the fuel cell performance. At least in some tests, molten carbonate also appeared to have leaked through cracks in the button cell itself, although confirmation is difficult because the cell can become distorted when cooled because of the shrinkage that occurs in the electrolyte.

Another key challenge identified was the reloading of an anode chamber that was less than $5 \mathrm{~mm}$ in thickness. The selected method was to entrain carbon in an inert gas and pump the mixture into the bottom of the anode chamber. Initial tests to determine the feasibility of this method indicated that as the anode chamber was thinned, the bubbles carrying the carbon particles became more volatile due to the small space and tended to push the carbon in the anode chamber out of the cell. Efforts to dampen the effect of the bubbles did not yield positive results.

The team felt that the hybrid electrode approach would yield the required power upon further optimization. However, the challenge of molten carbonate cracking the thinner structure was considerable and would clearly require substantive investigation and research. CEL decided that the resources required were beyond the scope of its current funding, and further research was stopped.

\section{Conclusions}

\subsection{The primary challenge: DCFC}

The primary challenge in DCFC technology is delivering adequate power and efficiency simultaneously:

- The DCFC can produce approximately $180 \mathrm{~mW} \mathrm{~cm}^{-2}$ at high temperatures; however, at these temperatures, the reverse Boudouard reaction is dominant, and the cell is running on $\mathrm{CO}$ rather than the carbon.

- Decreasing the temperature, at the detriment of power, does not fully solve the Boudouard problem. A method of turning off the $\mathrm{CO}$ in the bed of carbon was not discovered, as $\mathrm{CO}$ appears to be integral to how the cell performs.

- To reduce the likelihood of the carbon converting to $\mathrm{CO}$, the molten carbonate must ensure good contact between the electrolyte and the carbon particles. With good contact, full oxidation of the carbon (and therefore the efficiency of the cell) may be maintainable.

- Because of floating, bubble formation and mixing issues, the use of powdered carbon makes it difficult to both protect the carbon from the reverse Boudouard reaction and reload the carbon into the anode chamber.

- The reverse Boudouard reaction can be reduced using solid blocks of carbon; however, this approach makes reloading difficult and adds cost and complexity to the fuel manufacture.

- Reducing the temperature results in lower power output, thus increasing the total system size for a given power output (assuming no change in the DCFC construction). To allow lower temperatures, lower power output and sustained, adequate power density, a hybrid electrode system was proposed. 


\subsection{The primary challenges: DCFC hybrid electrode system}

- An improved loading mechanism is needed to reduce the effects of bubbling in the anode.

- Construction of the thin stackable anode chambers depicted in Fig. 17 is fairly simple; however, their durability in an environment where the molten carbonate electrolyte freezes once the cell is turned off is poor, resulting in shrinkage, distortions and cracks. Part of the reason why the hybrid electrode DCFC button cells were cracking is because scaffolding is only present on one side of the button. The SOFC design, where scaffolding is present on both sides of the YSZ, may help to balance the forces on the YSZ layer to prevent cracking. Without the second scaffolding layer, preventing cracking may be difficult.

Provided with adequate resources, the authors believe these primary issues can be overcome and move the DCFC from the laboratory to commercial readiness. However, this extension was well beyond the resources available at the time, and therefore, the project was ended.

\section{Acknowledgments}

Financial support for this work was provided by the Construction Engineering Research Laboratory (CERL), U.S. Army Engineer Research and Development Center (Contract \#W9132T-08-C0036), Ohio's Third Frontier Fuel Cell Program (Grant No. 09-022 and 09-058) and many private investors. The authors would like to thank the Wright Fuel Cell Group (Case Western Reserve University), Stark State Technical College and NASA Glenn Research Center. The authors would also like to acknowledge the contributions of Dr. Pallavi Pharkya and Dr. Abhishek Guha.

\section{References}

[1] T.A. Edison, US Patent No. 460, 1222 (1891).

[2] W.W. Jaques, US Patent No. 555, 511 (1896).

[3] D.X. Cao, Y. Sun, G.L. Wang, J. Power Sources 167 (2007) 250-257.

[4] J.F. Cooper, K. Berner, Presented in Fuel Cell Seminar, Direct Carbon Fuel Cel Workshop, Palm Springs, C.A, USA, 14th November 2005>

[5] J.F. Cooper, Presented in Direct Carbon Fuel Workshop, NETL, Pittsburg, PA USA, 30th July 2003.

[6] Army Energy Program, Key Energy Directives, http://army-energy.hqda pentagon.mil/policies/key directives.asp, (accessed 04.08.2011).

[7] S. Lux, F. Holcomb, R. Wolk, Proceedings from the Sixth International Fuel Cell Science, Engineering and Technology Conference, Denver, CO, USA, June 1618, 2008, FuelCell2008-65247.

[8] R. Wolk, S. Lux, S. Gelber, F. Holcomb, Direct Carbon Fuel Cells: Converting Waste to Electricity, Construction Engineering Research Laboratory, 2007, ERDC/CERL TR-07-32.

[9] N.J. Cherepy, R. Krueger, K.J. Fiet, A.F. Jankowski, J.F. Cooper, J. Electrochem. Soc. 152 (2005) 80-87.

[10] Confidential discussions with investors.

[11] C.-G. Lee, H. Hur, M.-B. Song, Oxidation behavior of carbon in a coin-type direct carbon fuel cell, J. Electrochem. Soc. 158 (4) (2011) B410-B415.

[12] R.D. Weaver, S.C. Leach, A.E. Bayce, L. Nanis, Direct Electrochemical Generation of Electricity from Coal, SRI, Menlo Park, CA 94025, 1979, SAN-0115 105-1; available from: NTIS.

[13] D.G. Vutetakis, D.R. Skidmore, H.J. Byker, J. Electrochem. Soc. 134 (1987) 3027 see also D. G. Vutetakis, Ph.D. Dissertation, Ohio State University, Columbus, $\mathrm{OH}$ (1985).

[14] D.G. Vutetakis, Electrochemical Oxidation of Carbonaceous Materials Dispersed in Molten Carbonate, University Microfilms Internal, Ann Arbor MI, 1985.

[15] J.F. Cooper, Proceedings of the 2nd International Conference on Fuel Cell Science, Engineering and Technology, Rochester, NY, USA, June 14-16, 2004, pp. 375-385.

[16] T.L. Cable, et al., Regenerative performance of the NASA symmetrical solid oxide fuel cell design, Intl. J. Appl. Ceramic Technol. 8 (1) (2011) 1-12.

[17] There are many variations of DCFCs, and the literature provides a good overview of these technologies: direct carbon fuel cells - fundamental and recent developments, J. Power Sources 167 (2007) 250-257.

[18] U.S. Patent Application No. 2007/0065701 A1, Application No. 11/218,185 (published March 22, 2007) (Cable et al. applicants). 